\title{
Prevalence and antimicrobial resistance of bacteria isolated from Beni-Guil lamb carcasses in eastern Morocco
}

Belhaj Kamal $^{1}$, Farid Mansouri², Darouiche Oumaima ${ }^{3}$, Khamri Mohamed ${ }^{3}$, Chaouki Belbachir ${ }^{3,4}$, Elamrani Ahmed ${ }^{1}$ ${ }^{1}$ Laboratory for Agricultural Productions Improvement, Biotechnology and Environment, Faculty of Sciences, University Mohammed First, BP-717, 60000 Oujda, Morocco

${ }^{1,2}$ Laboratory of Biochemistry, National Agency of Medicinal and Aromatic Plants, BP-159, 34000 Taounate, Morocco

${ }^{3}$ Regional Laboratory of Analysis and Research, National Office for Food Safety, BP 73, 60000 Oujda, Morocco

${ }^{4}$ Laboratory of Applied Chemistry and Environment, Faculty of Science, University Mohammed First, BP-717, 60000 Oujda, Morocco

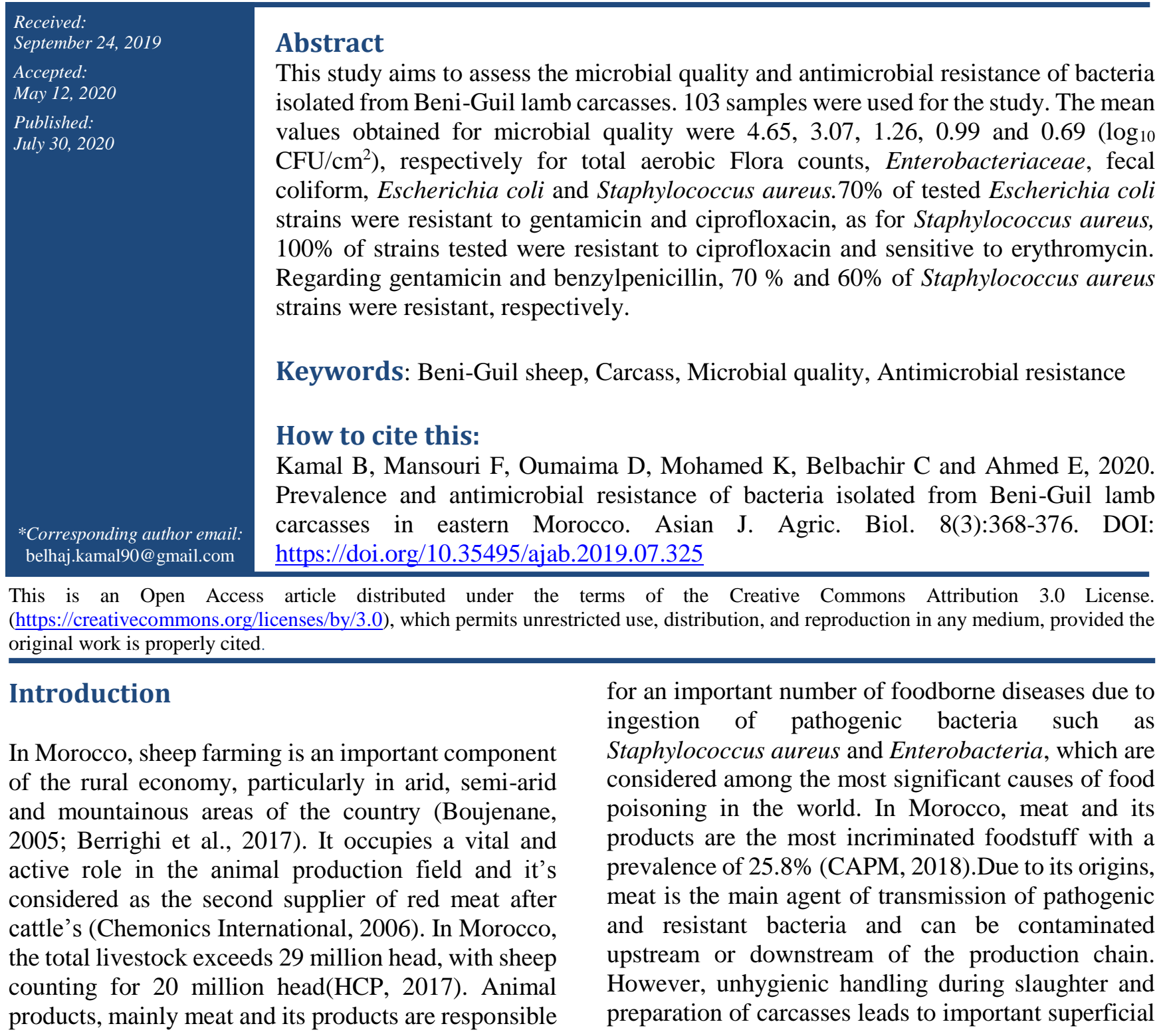


contamination which can affect the consumer's health and the meat quality (organoleptic deterioration) (Dennai et al., 2000). In Morocco, the slaughterhouse appears to be one of the major critical points in terms of meat hygiene. In fact, it is estimated, that 80 to $90 \%$ of the contaminations of meat by microflora arriving at consumers results from the slaughterhouse (Jouve, 1990).

Antimicrobial resistance is a major and global public threat to both human and animal health. This phenomenon has become a globally widespread problem. The monitoring of this problem plays an important and key role in sustainable development(Rather et al., 2017). It can infect anyone, anywhere. There are numerous mechanisms by which microorganisms acquire resistance to drugs. The latter can be encoded on the chromosome or on plasmid as a transmissible element. Lamb meat of the Beni-Guil breed labelled protected geographical indication is one of the main meats produced among Morocco meats. it is very appreciated by the consumer because of its taste and its nutritional quality (Belhaj et al., 2018).Although the meat microbiological quality has been the subject of numerous studies, to our knowledge, there are no studies, on one hand, on surface contamination of sheep carcasses using the not destructive method and, on the other hand, on the antimicrobial resistance of bacteria isolated from the surface of sheep carcasses. Considering the socioeconomic importance of this breed, and given the large consumption of its meat in the eastern regions as well as others regions of the country, it is important for us to study the microbiological risks associated to this foodstuff. The study revolves around the assessment of the microbial quality and antibiotic-resistance of bacteria isolated from the carcasses of Beni-Guil lamb.

\section{Material and Methods}

\section{Carcass sampling site}

In this study, 103 samples were tested. The sampling was carried out at tow slaughterhouses in the eastern region of Morocco during the year 2018 between March and May. The analyses were conducted in the Laboratory of Analysis and Research of the National Office for Food Safety which works according to quality assurance conditions (ISO 17025).

\section{Sampling and transport of samples}

The sampling methods, the selection of the collection sites and the rules for storage and transportation of samples have been made in accordance with ISO 17604. The sampling was carried out weekly. In the same slaughtering session, 5 carcasses were sampled before chilling. As for aerobic colony counts and Enterobacteria daily assessment, the $\log$ mean of 5 carcasses (4 areas of $100 \mathrm{~cm}^{2}$ on each carcass) was required. However, for Salmonella, 50 carcasses were needed for criteria assessment. The samples were collected aseptically, maintained at $6^{\circ} \mathrm{C}$ in a thermoelectric cooler with chiller ice packs, and transported to the laboratory.

\section{Microbiological test}

The microbiological tests were carried out on the same day. Among the isolated microorganisms, 20 bacteria (10 E. coli and $10 \mathrm{~S}$. aureus) were selected for the antibiotic resistance test.

All microbiological tests were carried out according to ISO standard methods: Enumeration of the Total Plate Count (TPC) in accordance with ISO 4833-1(ISO, 2013), enumeration Enterobacteriaceae in accordance with ISO 21528-2(ISO, 2017) and fecal coliforms using V 08-060(ISO, 2009). The enumeration of $S$. aureus was carried out in accordance with ISO 68882(ISO, 1999). The detections of Salmonella spp and Listeria monocytogenes were performed according to ISO 6579(ISO, 2002) and ISO 11290-1(ISO, 2004) respectively. Sample preparation and decimal dilutions were done according to the ISO 6887-2(ISO, 2010) standard method .

\section{Antibiotic resistance tests}

The study of antibiotic resistance was carried out in 3 essential steps according to the standards and recommendations of the French Society of microbiology's antibiogram committee "Comité de l'Antibiogramme de la Société Française de Microbiologie"(SFM, 2018):

- The culture of the purified bacterial strains (originally found in sheep carcasses) in Mueller-Hinton broth which is used as a non-selective medium to grow a very large number of bacteria of various origins by transferring them in the broth by using sterile inoculating loops and incubating at $37^{\circ} \mathrm{C}$ for 24 hours. Swab inoculation of the bacterial strains is grown in Mueller-Hinton broth on Mueller-Hinton agar Depositing of antibiotic discs, then incubation of agar plates at $37^{\circ} \mathrm{C}$ for 24 hours.

The isolated bacteria were tested against various families of antimicrobials, the following antibiotics were used: Amoxicillin $(25 \mu \mathrm{g})$, nitrofurantoin 
$(300 \mu \mathrm{g}), \quad$ Co-trimoxazole $\quad(1.25 / 3.75 \mu \mathrm{g})$, Erythromycin $(15 \mu \mathrm{g})$, Tetracycline $(30 \mu \mathrm{g})$, Thiamphenicol $(30 \mu \mathrm{g})$, Benzylpenicillin $(6 \mu \mathrm{g})$. For each antibiotic, the diameter of the inhibition zone was measured and the bacteria's clinical category in regard to each tested antibiotic (susceptible, intermediate, resistant) was determined (SFM, 2018).


Figure-1: ISO 17604 Suggested sampling sites for ruminants(ISO, 2015)

\section{Results and Discussion}

\section{Microbial quality of Beni-Guil sheep carcasses}

This research made it possible to evaluate the surface contamination of sheep carcasses of the Beni-Guil breed by counting indicators of hygienic quality (total aerobic mesophilic flora and enterobacteria) and searching for indicators of the sanitary quality of the carcass (Salmonella spp, listeria moncytogene, and Escherichia coli O157: H7).At the same time, a bacteriological investigation and evaluation of the materials, premises, equipment, staff members and working/operating conditions is was carried out.

The results of the bacteriological quality of the analyzed samples are presented in Table 2.The microbial quality of carcasses examined translates the hygienic measures adopted during the slaughter chain and post-processing of such perishable foodstuff. The results show that 20 bacteria were isolated $(10 \mathrm{E}$. coli and $10 \mathrm{~S}$. aureus), from 103 samples. The enumeration of the hygienic indicator criteria (hygienic quality) shows that the average value of germs is 4.65 $\log _{10} \mathrm{CFU} / \mathrm{cm}^{2}$ for ACC which constitutes the predominant flora, followed by Enterobacteriaceae with an average of $3.07 \log _{10} \mathrm{CFU} / \mathrm{cm}^{2}$, then $E$. coli and $S$. aureus with averages of 0.99 and $0.69 \log _{10}$ $\mathrm{CFU} / \mathrm{cm}^{2}$ respectively. The results of the microbiological analysis showed that $24.27 \%$ of samples are of satisfactory quality (below m), 29.12\% are of acceptable quality (between $\mathrm{m}$ and $\mathrm{M}$ ) and $46.61 \%$ are of unsatisfactory quality according to the standards (Table 1). Our results of TCC are lower than those reported by Mocho (2005) for sheep carcasses in France. However, they are higher than those reported by Okraszewska-Lasica et al. (2012) and Phillips et al. (2013) for sheep carcass in Ireland and Australia respectively.

Table-1. Acceptability threshold required in carcasses samples according to European standards.

\begin{tabular}{|c|c|c|c|l|l|}
\hline & $\begin{array}{l}\text { ACClog } 10 \\
\text { CFU/cm }\end{array}$ & $\begin{array}{l}\text { Enterobacte } \\
\text { rialog }{ }_{10} \mathrm{CFU} \\
/ \mathrm{cm}^{2}\end{array}$ & $\begin{array}{l}\text { Salmonella } \\
\text { sppin } 10 \mathrm{~g}\end{array}$ & $\begin{array}{l}\text { Listeria } \\
\text { monocyt } \\
\text { ogenes } \text { in } \\
10 \mathrm{~g}\end{array}$ & $\begin{array}{l}\text { E. coli } \\
\text { O157:H } \\
7\end{array}$ \\
\hline $\mathrm{m}$ & 3.5 & 1.5 & $\mathrm{Abs}$ & $\mathrm{Abs}$ & $\mathrm{Abs}$ \\
$\mathrm{M}$ & 5 & 2.5 & $\mathrm{Abs}$ & $\mathrm{Abs}$ & $\mathrm{Abs}$ \\
\hline
\end{tabular}

ACC: Aerobic Colony Counts; E. coli:Escherichia coli; m: fixed criterion; M: Maximum threshold or acceptability limit.

Table-2. Charge $\left(\log _{10} \mathrm{CFU} / \mathrm{cm}^{2}\right)$ of microorganisms in Beni-Guil carcasses samples collected in eastern Morocco

\begin{tabular}{|c|c|c|}
\hline & $\begin{array}{c}\text { Mean }\left(\log _{10} \text { CFU/c }\right. \\
\left.\text { m}^{2}\right) \pm \text { Standard } \\
\text { deviation }\end{array}$ & $\begin{array}{c}\text { Criteria }(m) \\
\left(\log _{10} \mathrm{CFU} / \mathrm{c}\right. \\
\left.\mathbf{m}^{2}\right)\end{array}$ \\
\hline ACC & $4.65 \pm 0.57$ & 3.5 \\
\hline Enterobacteriaceae & $3.07 \pm 0.71$ & 1.5 \\
\hline Fecal coliforms & $1.26 \pm 0.57$ & 1.5 \\
\hline E. coli & $0.99 \pm 0.65$ & --- \\
\hline S. Aureus & $0.69 \pm 0.64$ & --- \\
\hline Salmonella spp. & Abs & Abs \\
\hline $\begin{array}{l}\text { Listeria } \\
\text { monocytogenes }\end{array}$ & Abs & Abs \\
\hline E. coli O157:H7 & Abs & Abs \\
\hline
\end{tabular}

ACC: Aerobic Colony Counts; E. coli: Escherichia coli; S. Aureus: Staphylococcus aureus 
Concerning Enterobacteriaceae, the obtained average is higher than the one found by Okraszewska-Lasica et al. (2012) and Djenidi (2016) for sheep carcasses in Ireland and Algeria respectively. Regarding the fecal coliforms, the recorded values are lower than those reported by Goudiaby (2005), Mocho (2005) and Nouichi and Hamdi (2009) in Senegal, France and Algeria respectively. Meanwhile, they are higher than those reported by Okraszewska-Lasica et al. (2012) and by Omer et al. (2015). The obtained average value of Escherichia coli is higher than that reported by Phillips et al. (2013) in Australia. Finally, concerning the research of photogenic bacteria (safety criteria), our results show the absence of Salmonella spp, Listeria monocytogenes and E. coli $\mathrm{O} 157: \mathrm{H} 7$ in all analyzed samples. In comparison with the studies mentioned above, the Béni-Guil carcasses have a satisfactory sanitary quality, since Phillips et al. (2001), Nouichi and Hamdi (2009) and Hanlon et al. (2018) have indicated the presence of Salmonella spp and $E$. coli $\mathrm{O} 157: \mathrm{H} 7$ in small ruminant carcasses in Australia, Algeria and Bahamas respectively.

Regarding coagulase-positive Staphylococcus, our results are higher than those reported in sheep carcass in Australia by Phillips et al. (2013), however, they are lower than those reported by Djenidi (2016) in Algeria. Overall, the tested carcasses have a relatively high microbiological contamination indicating inadequate hygiene measures adopted during the preparation of this product. A similar result was reported by El Kadmiri et al. (2016) in Hay Hassani district-Casablanca (Morocco). This result can be explained as the cross-contamination of the carcass surface by finished and unfinished products which might have occurred due to contact with the skin or intestinal content during the skinning and evisceration step and by handlers from their hands in case of Staphylococcus aureus.Generally, the high-level contamination by superficial bacteria is an indicator of a lack of compliance with good manufacturing practices (GMP) and good slaughter practices (broken cold chain, improper cooling, hygiene and sanitation, etc.). So, the recorded difference between our study and the studies mentioned above can be clarified by GMP compliance and by the treatment of air and carcass surface by organic acids which decrease the surface contamination.

The results of the microbiological analyses of BeniGuil sheep carcasses can be explained by the results obtained from the evaluation of the bacteriological quality of the equipment and the environment of the slaughterhouse where the study took place. This evaluation made it possible to detect major hygienic defects (data is not shown).

In fact, hygienic defects were detected during the preparation of the animals (or first transformation). These are mainly issues with the hygiene of materials, premises, equipment, staff and working or operating conditions. The fundamentals of the go-forward principle and the separation of dirty and clean areas were not respected.The doors and openings remained open which facilitated the free circulation of wind, insects including flies and staff members from one sector to another, the latter can be potential vectors of microorganisms. Bleeding and skinning in the horizontal position, in other words in the lying down position, remains a traditional and ancient habit in the slaughtering process. This practice is the main source of carcass contamination. It is for this reason that the skin is considered a major critical point in terms of meat hygiene. To this, we must add, on one hand, the insufficient cleanliness of the animals before slaughter, illustrating a significant microbial load of the skin. On the other hand, there's also the bleeding carried out on the ground associated with the washing of the sheep. These practices increase the initial microbial load of the skin. Indeed, Fournaud et al. (1978) have obtained values five or even ten times greater than the initial microbial load of the skin, after a washing that was not followed by drying. The skin thus constitutes an important source of contamination of the carcasses. This skin contamination occurs mainly during dressing. It is now well established that the skin and the digestive tract are the 2 main sources of carcass contamination (Cartier and Moevi, 2007). The materials made with oxidizable iron were in a very advanced state of rusting. Their cleanliness and maintenance was insufficient. Thus, it was found that the wastewater drainage system was defective, particularly in the bleeding area due to the absence of gut protection grids. The rusty materials, unsatisfactory physical and hygienic maintenance of the equipment promote bacterial contamination of carcasses. Insufficient body and clothing hygiene make the staff the main vector of germs and contribute to the increase of the microbial load. Thus, the presence of foreign people (The meat wholesalers and their workers ...) during the slaughtering process constitutes a problem in terms of hygiene in the Oujda slaughterhouse. It is also noted that animal stalling and antemortem inspection are not systematic. This presents enormous risks, especially since this 
operation has an important objective concerning bacteremia (reduction of the microbial load of the digestive tract) and more or less the correction of defects due to fatigue and stress (biochemical quality of the meat), as well as the elimination of sick animals. Thus, for the improvement of the hygienic quality and a better control of the bacteriological quality of sheep carcasses of the Beni-Guil breed, the following recommendations are proposed to improve the general hygiene of the slaughter line:

Improvement of the hygiene of materials and premises (doors, openings, floor and equipment): use of stainless equipment, installation of cleaning and disinfection stations for staff, the implementation of a cleaning and disinfection system to properly maintain the premises and the equipment and the installation of doors and screens on all the openings on the walls and the floor, to prevent the penetration of unwanted animals: dogs, cats, insects.

Improvement of staff hygiene, providing the workers with work uniforms, monitoring of clothing hygiene, the prohibition of the entry of foreign people and prohibition of changing workstations.

The cleanliness of incoming animals: it is, therefore, necessary to reduce the number of very dirty animals arriving at the slaughterhouse. For this we can consider charging meat wholesalers for soiled animals. The creation of spacious, dry and mulched rest areas within slaughterhouses.

The succession of slaughter operations offers a multitude of possibilities for direct contact (turning of the leather, etc.) and indirect contact (via equipment, men, etc.) between muscle masses and sources of contamination. Slaughter hygiene, therefore, consists of minimizing this contamination as much as possible. This is why, today, the skinning hygiene rests first on the cleaning and disinfecting practices of the materials, if possible between each carcass, and on the specialization of hands and tools (one hand was affected during the handling of the leather, the other during the handling of the carcass).Skinning in an upright position is desirable to minimize contamination of carcasses by soil flora in order to avoid cross-contamination by the leather of other carcasses. Pressure rinsing of the carcasses after evisceration makes it possible to eliminate the microorganisms which follow the flow, and to consequently allow for a decrease in the bacterial load of the carcass surface on certain precise sites. Lenahan et al. (2010) have shown that washing after evisceration will reduce the microbial load on the surface of carcasses.

The harmonization of the cadence between the different phases of the slaughter line in order to avoid the overlapping of soiled and clean carcasses.

Lowering the carcass temperature as quickly as possible (refrigeration). However, care must be taken not to cause cryo-muscular shock (permanent contracture of myofibrils due to poor meat tenderness). This stage plays an important role in preserving the microbiological quality of fresh meats and determining their expiration dates.

\section{Antimicrobial resistance of isolated bacteria}

Widespread bacterial resistance is a serious risk to the whole population. This problem exists everywhere, especially in less developed countries due to selfmedication (Rather et al., 2017). Food is the main agent which transfers resistant bacterium. This transfer can occur by saprophytic, commensal and pathogenic bacteria or by the presence of antibiotic residues (Founou et al., 2016). Twenty bacteria among those isolated during the assessment of the carcasses' microbial quality were used for the study of the antibiotic-resistance, including 10 strains of E. Coli and 10 S. aureus(Table 3). The study of susceptibility towards antibiotics was carried out by using the diffusion in a solid medium method. Mueller-Hinton was the medium used in accordance with the standards and the recommendations of the French Society of microbiology's antibiogram committee (SFM, 2018). To evaluate the antimicrobial resistance of isolated bacteria we have tested 9 antibiotics belonging to 9 families of the frequentely used antibiotics in Morocco (amoxicillin, ciprofloxacin, gentamicin, erythromycin, benzylpenicillin, tetracycline, thiamphenicol, nitrofurantoin and the cotrimoxazoles) (El-Youbi et al., 2016). The results of antibiotic-resistance of bacteria isolated from Beni-Guil carcasses are presented in Table 3.

According to Table 3, the majority of the tested E. coli strains is resistant to more than three antibiotics (multidrug resistant). The ten $E$. coli strains tested have shown a resistance of $50 \%$ to tetracycline and nitrofurantoin, while $100 \%$ are resistant to ciprofloxacin and thiamphenicol. However, $100 \%$ of tested E. coli strains are sensitive to amoxicillin and $60 \%$ to gentamicin. As shown in table 3, E. coli strains have shown high resistance to the tested antibiotics. The highest resistances recorded were to ciprofloxacin (100\%), thiamphenicol (100\%), and nitrofurantoin (50\%). 
Belhaj Kamal et al.

Table-3. Antibiotic-resistance of Escherichia coli and Staphylococcus aureus strains isolated from BeniGuil's carcasses in eastern Morocco

\begin{tabular}{|l|c|c|c|c|c|c|c|c|c|c|}
\hline \multirow{2}{*}{ Antibiotic } & \multicolumn{3}{|c|}{ E. coli $(\%)$} & \multicolumn{2}{c|}{$\begin{array}{c}\text { Criteria for E. } \\
\text { coli }(\mathbf{m m})\end{array}$} & \multicolumn{3}{c|}{ S. aureus (\%) } & \multicolumn{2}{c|}{$\begin{array}{c}\text { Criteria for S. } \\
\text { aureus (mm) }\end{array}$} \\
\cline { 2 - 13 } & R & I & S & S & R & R & I & S & S & R \\
\hline Amoxicillin & 0 & 0 & 100 & $\geq 19$ & $<19$ & NT & NT & NT & - & - \\
\hline Ciprofloxacin & 100 & 0 & 0 & $\geq 26$ & $<24$ & 100 & 0 & 0 & $\geq 21$ & $<21$ \\
\hline Gentamycin & 0 & 40 & 60 & $\geq 17$ & $<14$ & 70 & 0 & 30 & $\geq 18$ & $<18$ \\
\hline Erythromycin & NT & NT & NT & - & - & 0 & 0 & 100 & $\geq 21$ & $<18$ \\
\hline Benzyl penicillin & NT & NT & NT & - & - & 80 & 0 & 20 & $\geq 26$ & $<26$ \\
\hline Tetracycline & 50 & 0 & 50 & $\geq 18$ & $<15$ & 50 & 25 & 25 & $\geq 22$ & $<19$ \\
\hline Thiamphenicol & 100 & 0 & 0 & $\geq 17$ & $<17$ & 85.71 & 0 & 14.28 & $\geq 18$ & $<18$ \\
\hline Nitrofurantoin & 50 & 25 & 25 & $\geq 11$ & $<11$ & 100 & 0 & 0 & $\geq 13$ & $<13$ \\
\hline Cotrimoxazole & 0 & 0 & 100 & $\geq 14$ & $<11$ & 0 & 0 & 100 & $\geq 17$ & $<14$ \\
\hline S:
\end{tabular}

S: Higher critical diameter; R: Lower critical diameter; R: Resistant; I: Intermediate; S; Sensitive; NT: Not tested

Whereas, all tested strains of $E$. coli are sensitive to amoxicillin and cotrimoxazole. An intermediate prevalence of resistance to gentamicin is dismonstrated $(40 \%)$. The recorded resistance to ciprofloxacin (quinolone family) is due to the fact that it's currently the most important group of antibiotics. Their effectiveness is related to their low toxicity and especially to the absence of plasmidic resistance (Fofana, 2004). This high recorded resistance to this family of antibiotics should be considered as alarming since the quinolones are antibiotics of last resort against Enterobacteria which is multidrug-resistant. The evolutionary nature of resistance mechanisms, therefore, calls for caution. Additionally, the obtained results for resistance to nitrofurantoin, thiamphenicol and ciprofloxacin are higher than those reported by Ravaonindrina et al. (2015) in Madagascar. This difference can be attributed to the intensification level of livestock production, since in Madagascar, livestock intensification is undeveloped. A similar result was reported for the resistance to ciprofloxacin by Van et al. (2008) in Vietnam.

The multidrug resistance of Staphylococcus aureus isolated in our study concerns antibiotics commonly used in veterinary medicine, in particular, beta-lactam, cyclines, cotrimoxazole, aminosides, macrolides and furane which are also used in the treatment of different bacterial infections in humans. The obtained results show that $100 \%$ of Staphylococcus aureus strains are resistant to ciprofloxacin and nitrofurantoin. Thus, $85.71,80,70$ and $50 \%$ are resistant to thiamphenicol, benzylpenicillin, gentamicin and tetracycline respectively. However, $100 \%$ of S. aureus isolated are susceptible to erythromycin and cotrimoxazole. The highest resistance percentages were found for the following antibiotics: ciprofloxacin and nitrofurantoin (100\%), thiamphenicol $(85.71 \%)$ and tetracycline (50\%). However, $100 \%$ of tested strains are sensitive to erythromycin and cotrimoxazole. The reason behind this high resistance to quinolone and furan could be explained by the excessive use in Morocco of these two families of antibiotics for curative or preventive purposes on animals. The obtained results are higher than those reported by Mercier (2003) for S. aureus isolated from goat carcasses. Concerning erythromycin, our results are lower than those found by Tefera et al. (2019) for S. aureus isolated from sheep and goat carcasses, however, the recorded resistance to the phenicol family is higher than that reported by Tefera et al. (2019). Except for the macrolide family (Erythromicin), Fthenakis (1998) had reported similar microbial resistance to betalactam (74\%), aminosides (70\%), and cyclin (44\%).Similar resistance was recorded against cotrimoxazole in comparison with the study of Hanson et al. (2011) on bacteria isolated from retail meat in Lowa.

The high rate of recorded antibiotic resistance based on this study, is mainly due to self-medication, as well as the use of extended-spectrum antibiotics, which cause the development of direct or indirect antibiotic resistance. These differences can be mainly explained by the negligence of the good use of practices and the intensification of animal husbandry. However, 
bacteria in the natural environment can harbor resistance genes derived from the use of these drugs in humans and animals. In adittion, this finding concerning the resistance to thiamphenicol (phenicol family) shoud be taken with consideration, since the latter is considered as a molecule that can cause fatal bone and irreversible medullar aplasia (HammettStabler and Johns, 1998).

The spread of multi-drug resistance (MDR) among pathogens is a global health risk because of its public health and economic incidence. The development of drug resistance among foodborne pathogens is mostly due to the abusive and anarchic use of antibiotics indicating a lack of adherence to treatment guidelines, overdosage, use of extended-spectrum antibiotics and the use of preventive agents as feed additives. Crossresistance has a chromosomal origin and it only concerns antibiotics that have the same mechanism of action, therefore having a common site of action. Thus, resistance to an antibiotic may be accompanied by resistance to other antibiotics of the same family. The tested bacterial strains have shown a resistance to multiple antibiotics, It's a case of MDR. The latter is defined as a single isolate resistant to three or more unique antimicrobial classes. A similar result was reported by several internationally prominent authors (Van et al., 2008; Hanson et al., 2011; El Allaoui et al., 2013; Ravaonindrina et al., 2015). Based on these results and the comparisons, it is quite evident that there is an increase of antibiotic resistance in the world, which represents a serious threat to humanity. This study could be a scientific basis upon which manuals for monitoring and controlling hygiene in Moroccan slaughterhouses can be established. Thus, the implementations of drug use guidelines for breeders to rationalize their usage, avoid selfmedication, and alternate antibiotics to reduce the development of bacterial resistance. So it would, therefore, be useful to deepen this study by following the evolution of carcass surface contamination during the animals' preparation for slaughter and investigating the origin of this contamination by resistant bacteria in order to determine whether said contamination is endogenous or exogenous.

\section{Conclusion}

The objectives of this study were the assessment of the bacteriological quality and to study the antibiotic resistance of bacteria isolated from Beni-Guil PGI lamb carcasses. From the health perspective, all the carcasses studied have a satisfactory quality (absence of pathogenic bacteria). Regarding the study of antimicrobial resistance, most of the tested strains were found to be resistant to antimicrobial agents, and they fall mostly into the critically important category, with a large percentage of multi-drug resistance isolates, which raises great concern for the health of consumers.

Disclaimer: None.

Conflict of Interest: None. Source of Funding: None.

\section{References}

Belhaj K, Mansouri F, Fauconnier M-L, Boukharta M, Caid HS, Sindic M and Elamrani A, 2018. Physicochemical and nutritional characteristics of Béni Guil lamb meat raised in eastern Morocco. Mediterr. J. Nutri Metab.11: 175-185.

Berrighi N, Belkacemi L, Bouderoua K, Santaella M, Ros G and Nieto G, 2017. Fatty Acids Composition and Sensory Properties of Lamb Meat Fed on Steppe and Highland Pastures. Asian J. Anim. Sci. 11: 88-95.

Boujenane I, 2005. Small ruminant breeds of Morocco, 5-54. In: INIGUEZ, L. (ed.) Characterization of small ruminant breeds in West Asia and North Africa. ICARDA Alepo, Syria.

CAPM, 2018. Centre antipoison met en garde les intoxications alimentaires [Online]. Casablance: Aujourd'huit la Maroc. Available: http://aujourdhui.ma/societe/le-centre-antipoisonmet-en-garde-contre-les-intoxicationsalimentaires [Accessed 10/01/2019 2019].

Cartier P and Moevi I, 2007. Le point sur la qualité des carcasses et des viandes de gros bovins. 70532 022 Paris: Institut d'élevage.

Chemonics International Inc., 2006. Promotion des viandes ovines a l'oriental. Abhat, Maroc. https://pdf.usaid.gov/pdf_docs/PNADH517.pdf

Dennai N, Kharrati B and El Yachioui M, 2000. Bovins à l'abattoir: Une microbiologie fluctuante. Viandes et produits carnés (Aubière). 21: 191-196.

Djenidi R, 2016. Étude de la contamination superficielle des carcasses ovines à l'aide d'examens bactériologiques au niveau de l'abattoir de Bordj Bou Arréridj. Revue Agriculture. 12: 47-56.

El-Youbi M, Belbachir C, Monir A and Saalaoui E, 2016. Antibiotics in broiler: exhaustive survey 
among private veterinarians in eastern Morocco. Moroccan J. Biol. 13: 2351-8456.

El Allaoui A, Rhazi Filali F and Oumokhtar B, 2013. Prevalence and antibiogram study of Escherichia coli and Staphylococcus aureus in turkey meat in Morocco. Pharmaceut. Anal. Acta. 4: 1-5.

El Kadmiri N, Bakouri H, Bassir F, Barmaki S, Rachad L, Nadifi S, El Kadmiri O and Amina B, 2016. Food hygiene assessment in catering establishments in Hay Hassani districtCasablanca. Pan Afr. Med. J. 24: 1-4.

Fofana A, 2004. Etude de la résistance aux antibiotiques des souches de Salmonella (spp) et de Escheichia coli isolées de la viande des poulets de chair au Sénégal.Doctorat, EISMV/UCAD, Dakar.

Founou LL, Founou RC and Essack SY, 2016. Antibiotic resistance in the food chain: a developing country-perspective. Front. Microbiol. 7: 1881.

Fournaud J, Graffino G, Rosset R and Jacque R, 1978. Contamination microbienne des carcasses aux abattoirs. Ind. Agric. Alim. 273 - 282.

Fthenakis G, 1998. Susceptibility to antibiotics of staphylococcal isolates from cases of ovine or bovine mastitis in Greece. Small Rumin. Res. 28: 9-13.

Goudiaby ML, 2005. Contribution à l'étude de la contamination superficielle des carcasses ovines aux abattoirs. Diplôme d'études approfondies de productions animales, Ecole Inter-Etats des Sciences et Médecine Vétérinaires (EISMV), Dakar.

Hammett-Stabler CA and Johns T, 1998. Laboratory guidelines for monitoring of antimicrobial drugs. Clin. Chem. 44: 1129-1140.

Hanlon KE, Echeverry A, Miller MF and Brashears MM, 2018. Establishment of a preliminary baseline of Salmonella presence on pork and goat carcasses harvested in the Bahamas to address food and nutritional security interventions. Anim. Front. 8: 26-32.

Hanson B, Dressler A, Harper A, Scheibel R, Wardyn S, Roberts L, Kroeger J and Smith T, 2011. Prevalence of Staphylococcus aureus and methicillin-resistant Staphylococcus aureus (MRSA) on retail meat in Iowa. J. Infect. Public Health. 4: 169-174.

HCP, 2017. Morocco in figures [Online]. Minèstre Marocaine. Available: https://www.hcp.ma/downloads/Maroc-en- chiffres_t13053.html [Accessed 17/10/2018 2018].

ISO, 1999. Microbiology of food and animal feeding stuffs -Horizontal method for the enumeration of coagulase-positive staphylococci (Staphylococcus aureus and other species)- Part 2: Technique using rabbit plasma fbrinogen agar medium (ISO 68882: 1999). International Organization for Standardization, Geneva.

ISO, 2002. Microbiology of food and animal feeding stuffs -Horizontal method for the detection of Salmonella spp. (ISO 6579: 2002). International Organization for Standardization, Geneva.

ISO, 2004. Microbiology of food and animal feeding stuffs -Horizontal method for the detection and enumeration of Listeria monocytogenes Part 1: Detection method (ISO 11290-1: 1996/AMD1:2004). International Organization for Standardization, Geneva.

ISO, 2009. Microbiology of food and animal feeding stuffs - Enumeration of thermotolerant coliforms by colony-count technique at $44{ }^{\circ} \mathrm{C}$ (NF V08-060: 2009).International Organization for Standardization, Geneva.

ISO, 2010. Microbiology of food and animal feeding stuffs -Preparation of test samples, initial suspension and decimal dilutions for microbiological examination (ISO 6887-5: 2010). International Organization for Standardization, Geneva.

ISO, 2013. Microbiology of the food chain -Horizontal method for the enumeration of microorganisms Part 1: Colony count at 30 degrees $\mathrm{C}$ by the pour plate technique (ISO 4833: 2003). International Organization for Standardization, Geneva.

ISO, 2015. Microbiology of the food chain-Carcass sampling for microbiological analysis (ISO 17604: 2015). International Organization for Standardization, Geneva.

ISO, 2017. Méthode horizontale pour la recherche et le dénombrement des Enterobacteriaceae -- partie 2: technique par comptage des colonies (ISO: 21528-2).International Organization for Standardization, Geneva.

Jouve J, 1990. Microbiologie alimentaire et filière viande. Viandes et produits carnés. 11: 207-213.

Lenahan M, O'Brien S, Kinsella K, Sweeney T and Sheridan J, 2010. Assessment of lamb carcass hygiene before and after chilling at five Irish abattoirs. Food Control. 21: 313-318. 
Mercier PP, M.-P., 2003. Évolution de l'antibiorésistance de souches de Staphylococcus aureus d'origine caprine en France. Rev. Med. Vet. 154: 277-280.

Mocho J-P, 2005. Evaluation de l'hygiène sur une chaîne d'abattage ovin à l'aide d'examens bactériologiques de surface des carcasses. Docteur, Université Paul-Sabatier, Toulouse.

Nouichi S and Hamdi TM, 2009. Superficial bacterial contamination of ovine and bovine carcasses at ElHarrach slaughterhouse (Algeria). Eur. J. Sci. Res. 38: 474-85.

Okraszewska-Lasica W, Bolton D, Sheridan J and Mcdowell D, 2012. Comparison of aerial counts at different sites in beef and sheep abattoirs and the relationship between aerial and beef carcass contamination. Food Microbiol. 32: 325-331.

Omer MK, Hauge SJ, Østensvik Ø, Moen B, Alvseike $\mathrm{O}$, Røtterud O-J, Prieto M, Dommersnes S, Nesteng $\mathrm{OH}$ and Nesbakken T, 2015. Effects of hygienic treatments during slaughtering on microbial dynamics and contamination of sheep meat. Int. J. Food Microbiol. 194: 7-14.

Phillips D, Sumner J, Alexander JF and Dutton KM, 2001. Microbiological quality of Australian sheep meat. J. Food Protect. 64: 697-700.

Phillips D, Tholath S, Jenson I and Sumner J, 2013. Microbiological quality of Australian sheep meat in 2011. Food Control. 31: 291-294.

Rather IA, Kim B-C, Bajpai VK and Park Y-H, 2017. Self-medication and antibiotic resistance: Crisis, current challenges, and prevention. Saudi J. Biol. Sci. 24: 808-812.
Ravaonindrina N, Razanajatovo I and Bastaraud A, 2015. Qualité microbiologique de la viande commercialisée dans la communauté urbaine d'Antananarivo. Rev. Elev. Méd. Vét. Pays Trop. 67: 122-123.

SFM, 2018. Comité de l'antibiogramme de la Société Française de Microbiologie recommandations 2018. Société française de Microbiologie, France.

Tefera M, Aleme H, Girma S, Ali A, Gugsa G, Abera F, Muzeyin R, Legesse T, Gobena W, Fentaw S, Abubaker R, Tadesse A and Gonfa A, 2019. Antimicrobial Susceptibility Pattern of S. aureus Isolated from Sheep and Goat Carcasses. Open Microbiol. J. 13: 16-20.

Van TTH, Chin J, Chapman T, Tran LT and Coloe PJ, 2008. Safety of raw meat and shellfish in Vietnam: an analysis of Escherichia coli isolations for antibiotic resistance and virulence genes. Int. J. Food Microbiol. 124: 217-223.

\section{Contribution of Authors}

Kamal B: Designed research methodology, data collection, analysis and manuscript writing Mansouri F: Statistical analysis and data interpretation

Oumaima D: Data collection and literature review Mohamed K: Data analysis and interpretation Belbachir C: Designed research methodology, data analysis and manuscript writing Ahmed E: Designed research methodology and manuscript final reading and approval 